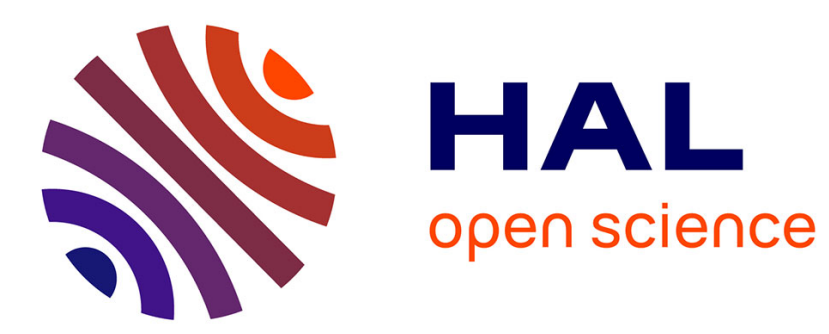

\title{
Non-trade concerns in agricultural and environmental economics: how J.R. Commons and Karl Polanyi can help us?
}

Denis Barthelemy, Martino Nieddu

\section{- To cite this version:}

Denis Barthelemy, Martino Nieddu. Non-trade concerns in agricultural and environmental economics: how J.R. Commons and Karl Polanyi can help us?. Annual meeting, Jan 2007, Chicago, United States. hal-02817728

\section{HAL Id: hal-02817728 \\ https://hal.inrae.fr/hal-02817728}

Submitted on 6 Jun 2020

HAL is a multi-disciplinary open access archive for the deposit and dissemination of scientific research documents, whether they are published or not. The documents may come from teaching and research institutions in France or abroad, or from public or private research centers.
L'archive ouverte pluridisciplinaire HAL, est destinée au dépôt et à la diffusion de documents scientifiques de niveau recherche, publiés ou non, émanant des établissements d'enseignement et de recherche français ou étrangers, des laboratoires publics ou privés. 


\title{
Non-Trade Concerns in Agricultural and Environmental Economics: How J.R. Commons and Karl Polanyi Can Help Us
}

\author{
Denis Barthélemy \\ and \\ Martino Nieddu
}

Some of conflict around agriculture in the World Trade Organization (WTO) is focused on Non Trade Concerns (NTCs). In the first section of this paper, we present how the Organization for Economic Co-operation and Development (OECD) connects these NTCs to the notion of multifunctionality and tries to promote its own "positive" approach. In the second section, we use J.R. Commons's conception to propose a specific interpretation of the OECD's position. This position implicitly constitutes a particular institutionalist practice aimed at reducing the multifunctionality of agriculture, while proposing recourse to the market as an “organizing social order.” But, Commons' point of view suggests that trade and non trade outputs result from the same institutional process, and therefore may not be analytically separated. In the third section, we use Polanyi's framework to suggest that NTCs cannot be considered as "non economic" items, but belong to the "substantive economy" where they take place with their own regulation, resource-allocation decisions, non market price system, and in opposition and complementarity to market economy.

\section{From Agricultural Market Liberalization to Multifunctionality}

In the 1980s, states apparently gave a single goal to agricultural policy: liberalize trade in agricultural products, making a substantial and progressive reduction in support and protection (Daugbjerg and Studsgaard 2005). Since the early 1990s, societal objectives have started to be explicitly considered with measures like "greening the agricultural policy” in Industrial Societies (Larkin et al. 1995; Laurent and Bowler 1997). Moreover, the 1994 Uruguay Round Agreement on Agriculture (URAA),

Denis Barthelemy is a Research Director at INRA, (France), MONA UR1217, Ivry sur Seine and Martino Nieddu is the head of Master Analyse et Décision Economique at Université de Reims Champagne-Ardenne (France) This paper was prepared for presentation at the Annual Meeting of the Association of Evolutionary Economics in Chicago, IL, January 5-7, 2007. We are greatly indebted to Richard V. Adkisson, Terrel Gallaway and Vicki Taggart for their constructive comments and advice. 
article 20, encouraged WTO member countries to "take into account . . non-trade concerns" and introduced the concept of multifunctionality. Multifunctionality means to produce several outputs at the same time. Thereby economists recognized that economic policies may include legitimate domestic objectives such as preserving family farms and rural landscapes or ensuring food safety, food security, and animal welfare. ${ }^{1}$ These concerns reflect a fear that free market expansion and globalization may undermine the provision of valued non-market amenities and cultural traditions associated with agriculture.

The OECD (2001) defined agricultural multifunctionality and proposed a guideline to analyze it in a document prepared in close connection with members of traditional agricultural and environmental economics. ${ }^{2}$ We wish to underline the two following points of this approach, which will subsequently be discussed.

The definition retained by $\operatorname{OECD}(2001,14)$ lets it be known that societal objectives are treated "in the context of empirical works," wherein multifunctionality seems to be a natural and objective characteristic of certain economic activities, whose feature is jointness in the production of commodity and non-commodity outputs. Therefore, sources of legitimate jointness are described as resulting from irreducible technological interdependencies, or the presence of non-allocable input or allocable fixed factors, what OECD calls multifunctionality's "positive definition." Other sources of jointness - social organization, firm's boundaries, cultural tradition, etc. would be considered "normative" ones, resulting from political choices and therefore less legitimate.

Jointness between production outputs induces market failures. The OECD's ideal multifunctional situation is that non-commodity outputs would be private goods that would give rise to specific markets ensuring efficiency in resource uses. Unfortunately "bad market goods" do exist, for instance in the case of "public goods." The OECD's problem becomes how to minimize public intervention, and "possible policy failures associated with incorrect estimation of the demand of public goods" (OECD 2001, 20). ${ }^{3}$ To solve it, the OECD proposes to divide the different aspects of "bad market goods." In this manner, it attempts to find a way for marketing some of them, for instance it separates use values and non-use values of the same public good, in the hope that market exclusion mechanisms may be instituted. ${ }^{4}$

\section{An Implicit Institutional Constructivism}

The OECD-recommended method attempts to make agriculture as little multifunctional as possible. Furthermore, we must point out that this method needs to use an underground institutionalist method (Barthélemy and Nieddu 2004). In this, we may recognize Commons's point of view, according to which markets are instituted. It allows us to criticize both sides of the position held by the OECD and economic mainstream in this field.

The OECD forwards the hypothesis that one can separate technical and political jointness, thereby making technical jointess legitimate, but not political. This is grounded in the belief that technical aspects could by themselves determine if 
something is a commodity or not, and also its value. Commons's Reasonable Value is clearly built up in opposition to this mainstream conception of Natural Value. "The ultimate unit of activity . . correlates law, economics and ethics" (Commons [1934] 1990, 58). Therefore, the technical dimension of an economical object may not be considered independently from the property definition, and the ability for being a commodity may not be considered as a natural feature of an object. ${ }^{5}$ Discussing materiality or immateriality of objects, Commons (652) lets us see that the latter aspect does not have economic meaning without the collective (judicial) decision to connect it with property determination. To take a basic example, jointness between hog production and negative environmental externalities did not economically exist before social damage was politically and judicially recognized (Hayden, 2005).

The relationship between private and public interest is not to be seen solely as an opposition. Although private interests may give rise to individual market efficiency, it always remains connected with collective efficiency. "Each economic transaction is a process of joint valuation by participants, wherein each is moved by diversity of interests, by dependence upon the others, and by the working rules which, for the time being, require conformity of transactions to collective action" (Commons [1934] 1990, 681). Market value can only appear after the market is instituted as the reasonable solution, given the context and time, to carry out the allocation of resources and goods among individual participants. "Commons viewed the choice of an appropriate institutional structure as the product of 'inescapable' societal value choices" (Schweikhardt 1988: 410). “. . . [T]he will of the individual is the collective will in action. His private purposes are public purposes to the extent that 'the public' through the determining power of its instruments . . . bring the collective power to his aid. ..." (Commons [1924] 1995, 365). The OECD and mainstream neo-classical economists' arguments look quite paradoxical in as much as they irreducibly place in opposition individual and public purposes, market and public goods, and promote the former when at the same time their propositions require collective action.

The OECD and mainstream economic ${ }^{6}$ position cannot be analyzed as a pure method of market coordination and allocation, but as a method that seeks to institute a specific economic regime of multifunctionality, even if not recognized: (a) it directs technologies and situations toward satisfying and reinforcing the separability of functions, and therefore the asserted distinction between natural and political jointness meets no legitimacy; (b) it separates the values of a single process in order to create separate markets as much as possible; but this operation demands collective choices, the criteria of which cannot solely be reduced to market efficiency. ${ }^{7}$

Coming back to the heart of the problem, how does one take into consideration the multiple functions of one single activity? We can see the will to separate as an attempt to deal with each function as if it were single. This is rooted in a specific and one-sided conception of the production process. Every production process takes place within a specific environment, and contributes to changing its state. The notion of "externality" is used in the peculiar cases where it is not possible to avoid the need of taking into account the consequences outside intention. But, the use of the word "externality" already takes for granted that there is an "inside" of a 
process to produce one-intended output (and therefore, unfortunately in some cases, a connection with the outside called externality), and gives us the conception of one single-output production process as being realistic. Nevertheless, in every case, whatever the intention may be, a new "state of things" is associated with every production activity. ${ }^{8}$

Agricultural multifunctionality is a good example in this field. It lets us see that there are two aspects. First, that commodities and non trade outputs are associated, and second, that they usually move in opposite directions, e.g., intensification of the agricultural process associated with the reduction of environmental quality. The OECD and mainstream economists try to avoid the debate by reducing the non trade outputs' weight and disconnecting the relationship by erecting an absolute opposition between private and public goods. Through the Reasonable Value notion, Commons demonstrates that marketable outputs and public goods result from the same institutional process, and therefore may not be so completely opposed. Nevertheless, how does one take into account that both aspects are opposed and complementary at the same time? It is Polanyi's approach that provides us with a way of confronting market rationality and non trade interest.

\section{Trade and NTCs Economic Relationships in a Synchronic Approach}

In The Great Transformation, Polanyi uses an analytical structure of a "double movement." "It can be personified as the action of two organizing principles in society. . . The one was the principle of economic liberalism, aiming at the establishment of a self-regulating market," and leading to "laisser-faire and free trade"; "the other was the principle of social protection aiming at the conservation of man and nature as well as productive organization," associated with "protective legislation, restrictive association, and others instruments of intervention" (Polanyi [1944] 1990, 138).

The multifunctionality debate arises in circumstances where the intensification of the agricultural process under market rationality meets the need to protect the environment, heritage value and food security. The latter concerns are part of what Polanyi calls "the principle of social protection aiming at the conservation of man and nature," and the former are clearly connected with "economic liberalism." Polanyi's analytical structure is fitting to our subject.

How can both aspects be dealt with? Each of them is a valid "general purpose" in itself, according to Commons. Thereby, they are in conflict without any "upper general purpose" to conciliate them. Polanyi gives the basic analytical structure, and develops it mainly in a diachronic way. The first movement is the rise of the market toward a "self regulated market" illusion and the destruction of every kind of protection of nature and communities under "the trading class" action (Polanyi [1944] 1990, 138). The second movement is the fall of the pure market dream and the rise of protections claimed by the "working and landed classes" (138). Following in Polanyi's wake, various authors studying multifunctionality are investigating the composition of social groups fighting for protection, with studies on 
Social movements for sustainable agriculture in France (Barham 1996) for instance, or 21st-Century transnational Peasant Movements (Edelman 2005).

However, Polanyi suggests another way. In opposition to the economic principle of formal rationality, "a sequence of acts of economizing" (Polanyi 1957, 378), he creates the "substantive economy" concept, where economy is defined as "the instituted process or culturally patterned arrangements by which a given human group provisions itself as a going concern. The focus is on the provisioning of social reproduction and on the instrumentality of economic activity vis-à-vis the life process" (Stanfield 1989, 269). Formal economy allows only one kind of behavior: maximize individual interest. In his substantive view of the economic process, Polanyi introduces other economic ways of proceeding, such that each human being taking part in economic activity may have several behaviors. ${ }^{9}$ This suggests synchronic analysis in which the double movement market/protection has to be viewed not as sequential but rather as simultaneous. Each class or group takes an interest in the market (the trading class of course, but working or peasant classes also in virtue of labor division and of separation of production and consumption) as well as in protection (tradesmen have families and need their future to be protected). ${ }^{10}$

The synchronic approach recognizes that for the same people, at the same moment in time, they are involved in both market relationships and protective non market economic relationships. European agricultural multifunctionality policy provides us with a good example. ${ }^{11}$

Although the term multifunctionality appeared in the 1990s, it was already in practice before. Common Agricultural Policy in the European Union was grounded in the Rome Treaty (1957), in which article 39 of the Treaty stated various objectives. Among them we find, "to increase agricultural productivity by . . . the optimum utilization of the factors of production" (\$1.a) where terminology suggests a developing market economy. Whereas $\$ 1 . b$ calls "to ensure a fair standard of living for the agricultural community" taking into account "the social structure of agriculture and from structural and natural disparities between the various agricultural regions." Paragraph 2.a specifies this protective objective in favor of the family farm, which was predominant at the time. Paragraph 1.b is incongruous with paragraph 1.a, which tends to promote competition inside agriculture, of course to the disadvantage of the family farm. This contradiction took concrete appearance with the Common Market Organization, which instituted European common agricultural markets, yet at the same time, distorted its operating through the introduction of price supports aimed at preserving adequate income to family farms all over the European territory.

As is well-known, these price supports gave rise to extra profits for larger farms and encouraged them to endless intensification and rise of production. This in turn, implied increasing support expenses and consequently, dumping on the world market. At the same time, market forces engendered pressure to industrialize processes, which implied increasing pollution, and the loss of landscape heritage (King 2000). These were consequences opposed to what one could have hoped for of traditional family farm activities. Both aspects provoked reforms. In the first period 
(1984-1992), it was by a first step toward reduction of market price supports and financial compensation of farmers' incomes, connected with some measures in favor of lower animal density, moderate use of fertilizers and pesticides and protection of small farms and disadvantaged regions (Barthélemy and David 2001). In the second period (1999-2003), the need for a multifunctional policy was explicitly assumed and reforms went further toward the suppression of price supports and better connection with world markets on the one hand, and on the other, to the organization of specific actions in favor of the environment, landscape, etc. (European Communities, Council Regulation $\left.n^{\circ} 1257 / 1999\right)$.

Protective and restoring measures have taken two forms. Some of them are compulsory rules farmers adopt in counterpart to that which remains as direct subsidies (eco-conditionality of premiums). Others, are proposed to farmers who may contract for specific actions. In this case, they get remuneration, whose price "shall be ... calculated on the basis of income foregone, additional costs resulting from the commitment given, and the need to provide an incentive" (E. C., Council Regulation $n^{\circ} 1257 / 1999$, art. 24). In both cases, protective measures (in the sense of Polanyi's principle of protection aiming at the conservation of man and nature) give rise to defined payments. It means that farmers are involved in a market economy where they have costs, produce commodities and get market prices for them. At the same time, they are involved in a protective economy, where they also have costs or lose potential income, produce a certain state of things and therefore get non market prices. Both economic insertions are connected since the level of global income depends on both income sources. Here, we have come back to the original debate. The mainstream economist tries to separate both aspects and reduce non market dimensions to marketable ones. As shown, their attempt is hopeless, for the state of the environment, heritage, employment or food security is simultaneously distinct from and intrinsically connected to commodity production, even in the case where specific actions are conducted.

\section{Conclusion}

The agricultural multifunctionality debate is of great interest because it echoes outside the realm of agriculture in other fields of economic activity. Agricultural multifunctional policy is often considered as unfair support to farmers facing world market competition, as well as an unjustified public charge. This is a one-sided view. Despite some farmer lobbies exploiting the situation, supports or specific non market payments have been intended from the beginning to maintain a certain state of agriculture, which would be altered by pure market action. Here, we encounter the kind of question Polanyi raised through the substantive economy notion, in other words an economic system which deals with the livelihood of human beings and its permanence.

Synchronic analytical perspective means we have to take account of the market and non market economy together. This in turn implies two price regulation systems, which react upon each other. In a sense we could speak of the mutual 
embeddedness of the market economy and the protective economy (for the latter we prefer the term "heritage economy," Barthélemy, Nieddu and Vivien 2005). Such a situation has already informed economists thought, for example, in the contribution of family economy or the protective regulation of market production and prices in diverse countries. We only underline the universality of this phenomenon, and the need to take it into account and adopt a holistic perspective. This can be attained only when we cease to accept the prevailing one-sided conception of economic production which omits the effect every production exerts on the state of the world.

\section{Notes}

1. Some frequently cited multifunctions of agriculture are environmental and social: scenic vistas, traditional country life, wildlife habitat, small farm structure, flood control, cultural heritage, rural development and food security, rural income and employment, elimination of hunger, viability of rural, rural income and communities, secure food supply (Mullarkey, Cooper and Skully 2001)

2. The theoretical OECD framework fits into a neoclassical perspective, and extends in two directions. First toward imperfect information, and second, through its recognition of transaction costs toward new institutionalist economics (NIE). Here we agree with Kaufman (2003) when he states: "Commons' point of view suggests that many NIE economists exaggerate the role played by transaction costs, contracting and hold-up problems in matters of economic organization and the extent to which efficiency considerations underlie observed patterns of economic organization" (94).

3. "Even if some commodity outputs are positive externalities that cause market failures, government intervention is not necessarily the best option . . . many options would require no or very limited government intervention such as to facilitate market creation" (OECD 2001, 20).

4. Use values represent the value associated with actual use; option value and quasi option value are the value of having the ability to make choices in an uncertain future. Two non-use values, existence values and bequest values represent ecological values (the value that humans attach to the simple fact of a resource's existence without wishing to consume it and the value that humans attach to the possibility of preserving a resource for future generations) (OECD 2001, 80).

5. On the close connection between the technical and legal aspects that define economic goods, see also, Barthélemy, Boinon, and Nieddu (2003). On the fact that "Commons rejected both mechanical equilibrium and natural selection analogies" to argue in an institutionalist point of view, see Rutherford (1994, 261 and 261-269), and Atkinson and Reed (1990).

6. Lamb (2003) suggests that it is best to let market forces guide the evolution of agriculture. Schmitz and Moss (2005) argue that market incentives are more efficient ways to deal with non trade concerns.

7. We have seen the various values integrated in mainstream theory to integrate futurity. In the constraints of the present text, we are unable to discuss the notion of use value itself. Following Commons's interpretation of the classical literature; Stern (1999) shows that we have to make distinctions between "exchange scarcity" and "use scarcity" (470).

8. Thomassin and Cloutier (2004) analyze the conflict resulting from environmental pollution as a byproduct of swine production. We agree with them on their use of Commons's "strategic transaction" concept. Nevertheless, producers of swine are both producers and residents and the problem is not only the conflict of interest among groups but also the conflict within the individuals themselves.

9. Polanyi said that no society could live unless it possessed an economy of some sort; but previous to our time no economy has ever existed that, even in principle, was controlled by markets (Lewis and Von Ende 1994). Polanyi, Arensberg and Pearson ([1957] 1965) conclude in their preface of "Trade and Market" by saying: "let the reader judge . . . the joint efforts of institutional economists and anthropologists in the other treatments of problems in different or alternative economic behaviors, motives, and systems in this book." 
10. In opposition to Marx, Polanyi thought that a class interpretation of interests could not capture the multiple ways in which personal preferences and attitudes are formed (Block and Somers 1984). According to Barham (1996), this point is crucial to his understanding of how collective social protectionist action took place. Individual interests were formed in a variety of ways, expansion of the market economy affected groups within society in many different ways. Social groups that appeared to hold divergent interests on the surface could therefore eventually find it natural to cooperate. Also, Stanfield $(1989,275)$ states: “. . . it is not valid to present the protective state interventions as resulting from a leftward ideological shift ... Very often the programs were enacted by those quite enamored with a pro-market ideology. The comprehensive feature is not ideology or political power group but the necessity of countering the disruptions of the market process."

11. Japan (Simpson and Schoenbaum 2003), the United States and many other countries (Prestegard 2004) develop the same kind of policies with slight differences. The European Union case is easier to analyze since negotiations between country members necessitates providing explicit argumentations.

\section{References}

Atkinson, Glen, and Mike Reed. "Institutional Adjustment, Instrumental Efficiency and Reasonable Value." Journal of Economic Issues 24, 4 (1990): 1095-1107.

Barham, Elizabeth. "Social movements for sustainable agriculture in France: A Polanyian perspective." Society $\mathcal{E}$ Natural Resources 10, 3 (1996): 239-250.

Barthélemy, Denis, and Jean David (eds). Production Rights in European Agriculture. Paris: INRA-Editions and Amsterdam: Elsevier, 2001.

Barthélemy, Denis, Martino Nieddu, and Franck-Dominique Vivien. "Economie patrimoniale, identité et marché." In Réinventer le patrimoine. De la culture à l'économie, une nouvelle pensée du patrimoine? edited by Christian Barrère, Denis Barthélémy, Martino Nieddu, and Franck-Dominique Viviens, 121-150. Paris: L'Harmattan, Collection Gestion de la culture, 2005.

Barthélemy, Denis, Jean-Pierre Boinon, and Martino Nieddu. "Le dualisme comportemental des agriculteurs: une interprétation institutionnaliste dialectique." Economie et Institutions 3, (2003): $131-64$.

Barthélemy, Denis, and Martino Nieddu. "Multifunctionality as a concept of duality in economics: an institutionalist approach." Rennes: 90. EAAE seminar: Multifunctional agriculture, policies and markets: understanding the critical linkage. European Association of Agricultural Economists, October 28-29, 2004.

Block, Fred, and Margaret R. Somers. "Beyond the economistic fallacy: The holistic social science of Karl Polanyi." In Vision and Method in Historical Sociology, edited by T. Skocpol, 47-84. New York: Cambridge University Press, 1984.

Commons, John R. Institutional Economics. New Brunswick (NJ), and London (UK): Transaction Publishers, [1934] 1990.

—. Legal Foundations of Capitalism. New Brunswick (NJ), and London (UK): Transaction Publishers, [1924] 1995.

Daugbjerg, Carsten, and Jacob Studsgaard. "Issue Redefinition, Venue Change and Radical Agricultural Policy Reforms in Sweden and New Zealand." Scandinavian Political Studies 28, 2 (2005): 103. 123.

Edelman, Marc. "Bringing the Moral Economy back in ... to the study of 21st-Century transnational Peasant Movements." American Anthropologist 107, 3 (2005): 331-345.

European Council. "Council Regulation (EC) n¹257/1999" of 17 may 1999, "Official Journal of the European Communities, L.160/80, 26.06.1999, (1999) http://ec.europa.eu/agriculture/rur/ leg/1257_en.pdf

Hayden, Gregory F. "Combining Equity and the Precautionary Principle: Examples Drawn from Hog production in Poland." Journal of Economic Issues 39, 2 (2005): 357-364.

Hill, Lewis E., and Eleanor T. Von Ende. "Towards a personal knowledge of economic history: reflections on our intellectual heritage from the Polanyi Brothers." The American Journal of Economics and Sociology 53, 1 (1994): 17-27. 
Kaufman, Bruce E. "The organization of economic activity: insights from the institutional theory of John R. Commons." Journal of Economic Behavior and Organization 52 (2003): 71-96.

King, Martin Bruce. "Interpreting the Consequences of Midwestern Agricultural Industrialization." Journal of Economic Issues 34, 2 (2000): 425-434.

Lamb, Russell L. "The new farm economy: the agriculture industry has entered the 21st century; perhaps farm policy will do so as well.” Regulation 26, 4 (2003): 10-16.

Larkin, Andrew, David Vail, Knut Per Haslund, and Lars Drake. "The Greening of Agricultural Policy in Industrial Societies: Swedish Reforms in Comparative Perspective." Journal of Economic Issues 29, 3 (1995): 968-971.

Laurent, Catherine, and Ian Bowler. CAP and the regions, building a Multidisciplinary Framework for the analysis of the EU Agricultural Space. Versailles, France: Inra-Edition, 1997.

Mullarkey, Daniel, Joseph Cooper, and David Skully. "'Multifunctionality' and Agriculture: Do Mixed Goals Distort Trade?" Choices: The Magazine of Food, Farm EO Resource Issues 16, 1 (2001): 31-35.

Organization for Economic Co-operation and Development (OECD). Multifunctionality, Towards an Analytical Framework. Paris: OEDC Editions, 2001.

Polanyi Karl. The Great Transformation, The Political and Economic Origins of Our Time. Boston: Bacon Press, [1944] 2001.

Polanyi, Karl, Conrad M. Arensberg, and Harry W. Pearson. "Trade and market in Early Empire, Economies in History and Theory." New York: The Free Press, [1957] 1965.

Prestegard, Sjur Spildo. "Multifunctional agriculture, policy measures and the WTO: the Norwegian case." Oslo: Acta Agric. Scand., Sect. C, Food Economics 1 (2004): 151-162.

Rutheford, Malcolm. "Predatory practice or Reasonable Values? American Institutionalists on the Nature of Market Transactions." History of Political Economy 6 (supp.) (1994): 253-276.

Schmitz, Andrew, and Charles B. Moss. "Multifunctionality in agriculture: externalities and non-traded goods." Int. J. Agricultural Resources Governance and Ecology 4, 3-4 (2005): 327-348.

Schweikhardt, David B. "The Role of Values in Economic Theory and Policy: A Comparison of Frank Knight and John R. Commons." Journal of Economic Issues 32, 2 (1988): 407-14.

Stanfield, J. Ron. "Karl Polanyi and contemporary economic thought." Review of Social Economy 47, 3 (1989): 266-280.

Stern, David I. "Use value, exchange value, and resource scarcity." Energy Policy 27 (1999): 469-476.

Simpson, James R. and Thomas J. Schoenbaum. "Non-trade Concerns in WTO Trade Negotiations: Legal and Legitimate Reasons for Revising the 'Box' System.” Int. J. Agricultural Resources, Governance and Ecology Vol. 2, n³/4, (2003) : 399-410.

Thomassin, Paul J., and Martin L. Cloutier. "The evolution of environmental legislation: a strategic transaction approach." Journal of Economic Issues 38, 2 (2004): 493-503. 
